\title{
Social Welfare for Disabled Communities
}

\author{
Prantasi Harmi Tjahjanti \\ Fakultas Teknik \\ Universitas Muhammadiyah Sidoarjo \\ Sidoarjo, Indonesia \\ prantasiharmi@umsida.ac.id
}

\author{
Wiwik Sumarmi \\ Fakultas Teknik \\ Universitas Muhammadiyah Sidoarjo \\ Sidoarjo, Indonesia
}

\author{
Edi Widodo \\ Fakultas Teknik \\ Universitas Muhammadiyah Sidoarjo \\ Sidoarjo, Indonesia
}

\begin{abstract}
In order to social welfare for disabled community should be started from the environment of disability since childhood. Increasing social welfare for disability society among others must be understood together that people with disabilities require recognition of their existence as individuals and social beings who have capabilities and potential that is not much different from normal people. They also need the recognition and acceptance of parents, families and communities with disabilities. Children with disabilities can achieve success in their lives when they have opportunity and support from their parents. But really there are still many parents who are more focused on the lack and the way of handling children, compared with digging the strength of the child. The role of the government towards Person with Disability (PwDs) is not as expected, and the disabilities also require public/ accessibility services that can support all its activities and access work in accordance with its ability.
\end{abstract}

Keywords—social welfare; disabled communities; parents; families and communities with disabilities; the role of the government towards Person with Disability (PwDs).

\section{INTRODUCTION}

In order to social welfare for disabled community should start from the environment of disability since childhood. The condition of disability is the condition of persons with physical, intellectual, mental, and / or physical limitations sensory influences on their development. There are several types of disability, namely tuna daksa (physical disability) [1] is a condition of the body that generally has the physical inability of the body to perform its functions. Characteristics include: (a) The limb is incomplete, or is not fully functional, (b) The limb shape and spine are abnormal, (c) Limited ability of motion, (d) There are obstacles in carrying out daily activities. Definitively understanding the abnormalities of limb function (physical disability) ) is the inability of the limb to perform its function due to the reduced ability of the limb to perform the normal function due to injury, disease, or imperfect growth [2]. According to the Ministry of Social Affairs quoted by Mangunsong [3] that physical disability is defined as the incompleteness of the limbs due to innate factors, accidental, or consequent diseases that cause disruption of the mobility, eg hand/ legs amputation, paraplegia, bone deformities, and cerebral palsy.

Tuna grahita is a condition that has a level of intelligence below the average age of his child, accompanied by an inability to adapt to the environment. Characteristics include: (a) Having intelligence (IQ) below 70, (b) Having a high dependence on others, (c) Less responsive or less able to adapt to the environment, (d) Slow speech development and development limited language.

Other types of disabilities are Learning Difficulties distinguished into:

- Difficulty Learning to Read (Dyslexia). Characteristics include: (a) having interruptions in reading, writing, and arithmetic, (b) reading slowly, (c) reading wrong words, (d) having letters in unreadable words, (e) word, (f) It is difficult to capture the contents of the reading, $(\mathrm{g})$ Difficult to spell.

- Learning Difficulties to Write (Disgrafia). Characteristics include (a) Slow when writing, (b) Difficulty using spaces between letters or between words, (c) Writing unreadable by others and themselves, (d) Writing too thin or too pressing, (e) Often writing numbers or different letters similar to each other.

- Learning Difficulty Learning (Diskalkulia) Characteristics include interference in: (a) Counting process (addition, subtraction, multiplication, division), (b) Knowing and understanding the symbol of numbers, (c) Differentiating top down, left right, front behind, and others.

Disability Tuna Laras is a condition that has problems or barriers in controlling emotions and social control. Characteristics include: (a) Behaving deviating from norms and or rules, (b) Being rebellious, (c) Easily angry and abusive. Furthermore, people with disability Blindness is having a visual impairment in both the Total Blindness that is not able to see anything and Low Vision (i.e. Medium Disorder) is still having the rest of the vision that cannot be assisted with ordinary glasses, but can still be functioned with the tool non optical optical vision aid and environmental modification. While hearing impaired speech impairment is differentiated into Lightweight Deaf, which can still hear and Deaf heavily i.e. can not hear. The characteristic of this 
disability is to have a written communication of oral communication due to the loss of all or part of its hearing power. They use gestures in communicating. Sometimes they have a high degree of awareness and a sensitive feeling that can get angry and irritable.

Double disability is one that has more than one disability. Characteristics are: (a) Having more than one disability (deaf and blind, blind and neutral, blind and denied etc.), (b) Unstable emotions, and (c) experiencing motion, sensory, and intelligence.

In addition. there are conditions since childhood has occurred in children who are also categorized as disability, among others: (1) Hyperactive Children are children who have attention disorders, self-control, emotions, and behavior. Children with Disorder and Hyperactivity Disorder (GPPH) disorders with characteristics include: (a) Unable to calm down, (b) Relentless, (c) Impatient behavior but still have the ability to give attention and responsibility.Often spend time doing something that is self-interested. (2) Autism Children Autism is a child who has neurodevelopmental disorders that affect the child's ability in communication, social interaction, and behavior. The characteristics include: avoiding the gaze of others, experiencing difficulty in making friends, speaking disorders, repetitive movements, and repeating the words of others ("membeo"). (3) Intelligent Children and or Special Talents are children of extraordinary intelligence or those who excel in specific academic and non-academic fields such as art (singing, dancing, painting, music), sports, and more. Has characteristics such as: having a level of intelligence (IQ) above 130, high learning achievement, have a high interest in problem solving, memory and high absorption. Widespread vocabulary, and solve problems faster than children their age.

The problem that arises is how to take care of such children from childhood until they grow up so they have social welfare and are ready to mingle with "normal" society in general.

\section{LITERATURE REVIEW}

This view of life in self, family, society and government is closely related to the problems faced by people with disabilities. Disability-related issues faced by people with disabilities are:

\section{A. Internal Issues}

1) Concerning the physical condition, which can lead to disruption of the ability of physics to do something deed or a particular movement associated with activities of daily life.

2) Concerning a person's mental psyche, due to disability a person becomes inferior or someone becomes inferior or otherwise, appreciates himself too much, irritable, sometimes aggressive, pessimistic, unstable, difficult to make decisions. All can be disadvantageous, especially with regard

to the relationship between humans and awkward in carrying out its social functions.

3) Educational problems, physical disabilities often cause difficulties, especially in school-aged children. They need special attention both from parents and teachers at school. Most of these difficulties also involve transportation between residence and school, difficulties in using school equipment and other public facilities.

4) Economic problems, illustrated by the existence of life of people with disabilities that generally are below the poverty line. This is due to its low income. Low productivity levels due to physical and spiritual weakness to lack of work skills (production) and the presence of barriers within the psychological structure, resulting in inabilityinside

carry out its social functions.

5) The problem of the appearance of social role in the inability of relationships between individuals, social interaction, community and participate in the environment.

\section{B. External Issues}

1) Family problems that arise embarrassment due to one of his family members with disabilities. As a result children do not go to school, should not hang out with peers, lack of love so that children can not develop ability and personality. Furthermore, the disabled person remains the burden of his family.

2) The problem of society, people who have disabled citizens of the body will be disrupted his life, as long as people with disabilities can not stand alone and always rely on others. From an economic point of view, since a person, especially an adult, becomes disabled, the community suffers a double loss, that is, the loss of productive members and increased consumptive members of society, which adds a heavy burden to society. Therefore it is necessary rehabilitation efforts that can change the body from the consumptive conditions to be productive. Besides, there are still attitudes and assumptions of some people who are less profitable for people with disabilities, among others, still a hesitant attitude to the ability (potential) of people with disabilities, the attitude of ignorance in the layers of society to the problem of people with disabilities, has not expanded participation the community in handling disability problems, the weakness of social organization that operates in the field of disability in carrying out its operation, there is still a society assumption that the worker with disability body is less potential than the labor is not disabled, the user of the employment of people with disability generally have not provide ease auxiliary tools needed for workers with disabilities, medical rehabilitation programs, social rehabilitation and vocational rehabilitation conducted by the government and society have not reached the entire population with disabilities and there is still very limited accessibility for independence in work, such as the provision of housing, transportation and certain types of work in accordance with the type of disability and other public facilities.

According to [4] basically humans have five basic needs that form the levels or hierarchy that is structured based on the most important needs to the unimportant and from the easy to the difficult to achieve or obtain. These needs are: a) 
Physiological needs ie clothing, food, boards and biological needs; b) Security and safety needs that are free of colonialism, free of threat, free from pain, and free from terror; c) Social needs of friends, family, and love needs of the opposite sex; d) The need for appreciation, in the form of praise, charter, service mark, and prize; and e) The need for self-actualization is the need and desire to act at will according to his / her talents and interests.

Fulfill physical needs i.e. eating, clothing, places stay, health, education and employment access. Meeting the needs of the psychic form of attention and affection both from the family environment and society. Fulfillment of social needs in the form of acceptance and appreciation from family and community. The need is a need that is general meaning that everyone has the same needs. People with disabilities as people with physical limitations have special needs such as accessibility and mobility requirements such as wheelchairs, wheelchair-specific rooms, ramps, orthese and prothese aids.

\section{METHOD}

Research methodology using data collection techniques, namely: (1) Research Library (Library Research) is a form of research in data collection. This study focuses on searching data information on books, articles, scientific journals, and other scientific works relevant to the writing of this research. (2) Access of Website and Official Website. Internet surfing is also an important part in finding referrals. The literature sources become an important part in the preparation of research. Search for resources via the internet, electronic books and articles related to the issues reviewed. This is done to supplement additional information and data in the preparation of this research. (3) Field Research is one of the ways used to obtain information other than through library research and access on the official website. The data source uses two types of data sourced from the primary data is data obtained directly from the source data and has the original data or new data (up to date). While secondary data is data obtained from or collected authors from various sources that already exist. Secondary data also obtained from various existing literatures related to disability issues. Furthermore, data analysis is processed in the form of qualitative dekskriktif method. Completely poured in the flow diagram of Figure 1.

\section{RESULTS AND DISCUSSION}

For children with disabilities, the most important thing is to hone their interests and talents by providing various stimuli and encouragement to excel. Giving an opportunity to ask questions and explore the talents of the child. Appreciate the child's business. Their needs are basically the same, among others, the need to love, make friends, play, study, and attend school. Children with disabilities prior to school by parents are: early detection of child development with consultation to the doctor or experts, cultivate a sense of affection, and share pleasure and distress to others, teach norms and rules, to know where which can and should not be done, foster self- confidence, provide training for children to help and take care of themselves, teach children how to communicate with others, and support growth and development according to capacity of ability.

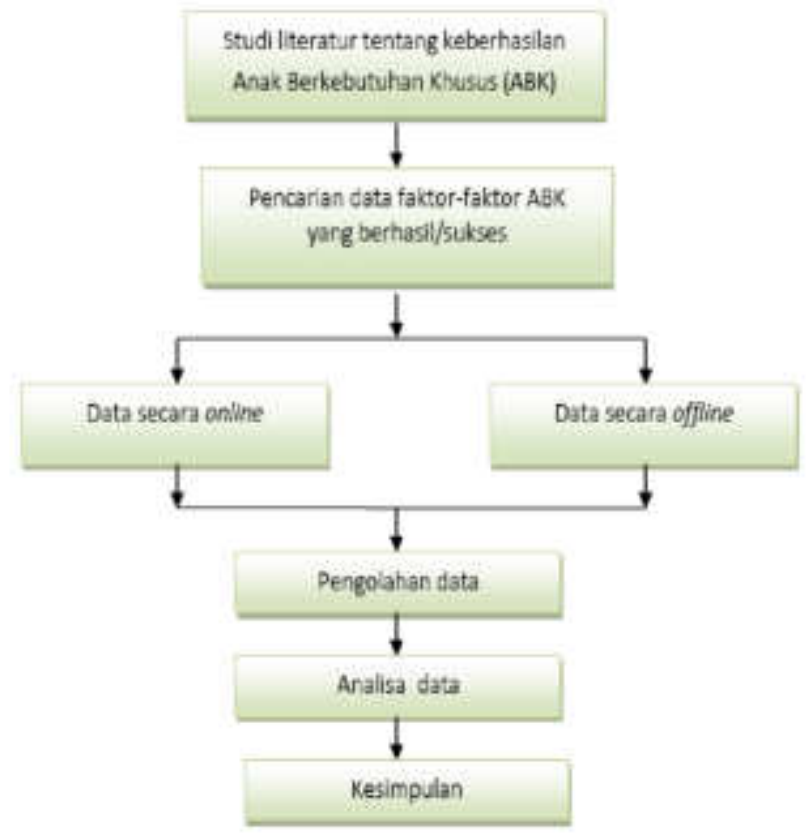

Fig. 1. Research of flow diagram

While in school is to guide children to worship, explore talents and interests of children, provide opportunities to be friends and play with children his age, establish communication with the school in the process of children's education, actively involved in activities at school, prepare and assist children in aqil balig, providing guidance to the child during aqil balig period, helping children maintain cleanliness during menstrual periods in girls and wet dreams in boys, adjusting skills needed in their child's education, and preparing children to design their future.

In the period before SMALB/ high school/ SMK, then what is done is to develop talents and interests, guide and assist the child in doing the work in accordance with his profession, guide and prepare the child to marry. In detail the care of persons with disabilities is described as follows: (1) Tunadaksa: Provide self-guidance and bodybuilding guidance, eg self-care, self-care, self-help, and motion exercises (motor fine and gross motor), (2) Tunagrahita: Giving guidance (3) Tuna Laras: Provide emotional, social, and religious guidance, (4) Blind people: Provide orientation and mobility guidance, for example to introduce the situation and direction in which the child is located, (5) Deafness and Speech: Giving guidance on perceptual communication of sounds and rhythms, for example training in arithmetic, (6) Tunaganda: Giving selfguidance and movement, (7) Learning Difficulties: Providing guidance on special learning in accordance with learning difficulties, (8) ) Hyperactive: Provides clear guidance of rules, such as making a deal of playing time, (9) Autism: 
Providing communication guidance and social interaction, eg train eye contact and speech, (10) Intelligent and Special Talents: Provide self-guidance, such as taking care of yourself, taking care of yourself, and helping yourself.

What next should parents do? The most important thing is to learn to accept the existence of children in accordance with the shortcomings and advantages. Learn as much as possible about the child's developmental barriers, such as talking to a family with children with the same obstacles, from books, magazines, relevant information, or asking the experts. Find out about services that are compatible with child disabilities, joining a parent community with children with the same disabilities, having outside activities that can motivate how to nurture children appropriately. Spend some time for recreation together with family,spend time talking with family, closest friends, and others, take care of children's health, learn to improve the competencies they must have in assisting children with disabilities, and encourage children to play with and learn with other children who are not disabled [5].

What about the role of school unit education in relation to parents who have children with disabilities. Educators ask for information about the child's developmental history at the start of school entry. Educators establish cooperative relationships with the school so that parents are always welcome to attend parent meetings with the school. Parents make visits to see teaching and learning activities in the classroom at least once a semester, and it is important to be a resource person for teachers and other parents, and to be involved in individual learning programming teams [6]

\section{CONCLUSION}

Some conclusions that can be taken to improve social welfare for disability communities. First, it should be understood that the person with disabilities of the body requires recognition of their existence as individuals and social beings who have the ability and potential that is not much different from normal people. They also need the recognition and acceptance of parents, families and communities with disabilities. Second, children with disabilities can achieve success in their lives when they have the opportunity and support of parents. But what happens, there are still many parents who are more focused on the lack and the way of handling children, compared with digging the strength of the child. Third, the role of the government towards PwDs though not as expected. The disabilities also require public services accessibility that can support all activities and access to work in accordance with its ability.

\section{ACKNOWLEDGEMENT}

The authors present their gratitude to Universitas Muhammadiyah Sidoarjo for facilitating article publication.

\section{REFERENCES}

[1] http://sahabatkeluarga.kemdikbud.go.id

[2] Efendi, M, 2009, Pengantar Psikopedagogik Anak Berkelainan, Jakarta : Bumi Aksara.

[3] Eny Hikmawati dan Chatarina Rusmiyati,2011, Kebutuhan Pelayanan Sosial Penyandang Cacat, Informasi, Vol. 16 No. 01 Tahun 2011.

[4] Maslow, A. H. (1970a). Motivation and personality. New York: Harper \& Row.

[5] Gusti Indah Pratiwi, 2016, Peran Pemerintah Dalam Perlindungan Sosial Penyandang Disabilitas Di Pekanbaru (Studi pada organisasi perkumpulan kesejahteraan penyandang cacat), Jom FISIP Vol. 3 No. 1 Februari 2016

[6] Rostiana \& Damayanti,S,2003, Dinamika emosi penyandang tunadaksa pasca kecelakaan, Jurnal Psikologi Arkhe, 1, 15-28. 